\title{
Association between Waist Circumference as Central Obesity Marker and Cooper Test Result in Security Personnel
}

\author{
Nathanael Nathanael ${ }^{1}$, Listya Tresnanti Mirtha ${ }^{2 *}$ and Muchtaruddin Mansyur ${ }^{3}$ \\ ${ }^{1}$ Faculty of Medicine, Universitas Indonesia, Jakarta, Jakarta Pusat, Indonesia; nathanael1_r@yahoo.com \\ ${ }^{2}$ Sports Medicine Division, Department of Community Medicine, Universitas Indonesia, Jakarta, \\ Jakarta Pusat, Indonesia; tresnanti.listya@ui.ac.id \\ ${ }^{3}$ Occupational Medicine Division, Department of Community Medicine, Universitas Indonesia, \\ Jakarta, Jakarta Pusat, Indonesia
}

\begin{abstract}
Background: Obesity is a problem that is found all over the world. Individuals who has increased of waist circumference or body mass index will have reduced physical fitness. This condition can also be found in security personnel who need great physical fitness for their occupation. Objectives: To find the correlation between waist circumference as marker of central obesity and Cooper test result in security personnel. Methods: This cross-sectional study was done to security personnel at Faculty of Medicine University as Indonesia with measuring waist circumference and Cooper test or 12-minutes run test distance covered. Result: From 43 subjects, we found that central or abdominal obesity prevalence is $27.9 \%$ and the mean of distance covered on Cooper test is $1787.41 \pm 271.71 \mathrm{~m}$. Spearman correlation test from both variables give significant inversely proportional correlation. ( $\mathrm{p}$ value $=0.02 ; \mathrm{r}=-0.430 ; 95 \% \mathrm{CI}=-0.672--0.150$ ). Conclusion: Increasing waist circumference in a person has correlation with decreasing physical fitness especially cardiorespiratory fitness.
\end{abstract}

Keywords: Cooper test distance covered, Obesity, Security personnel, Tes Kesamaptaan Jasmani, Waist circumference

\section{Introduction}

Globalization era gives simplicity in daily works. This condition results in decreasing physical exercise which also seen in Indonesia. Only $24,96 \%$ of people above 10 years in Indonesia that doing physical exersise ${ }^{1}$. Concequences which is non-communicable disease will affect both health and working performance including in security personnel ${ }^{2}$.

Physical exercise can decrease the mortality from non-communicable disease which is $70 \%$ regarding World Health Organization ${ }^{3}$. Beside that, physical fitness will also improve physical performance ${ }^{1}$. Unfortunatelly, majority of people still neglecting the importance of physical exercise for their health and working performance including security personnel who need greater level of body performance ${ }^{4}$. Therefore, security personnel candidate in Indonesia have to pass the SAMAPTA test which include Cooper test or 12 -minutes run test ${ }^{5}$.

Lack of physical exercise may result individuals with obesity ${ }^{3}$. World Health Organization state that 5, 8\% individuals in Indonesia have obesity from all categories ${ }^{6}$. Also, security personnel may be included in those population with decreasing physical performance. One sign of obesity is accumulation of fat in the abdomen which can be found in some security personnel ${ }^{7}$. Therefore, security personnel nutritional status must be monitored to prevent disturbance in their work.

Unfortunatelly, there is still no study on finding correlation between central obesity and physical fitness among security personnel in Indonesia. Therefore, this study aims to to investigate the assiciation between waist circumference as central obesity marker and distance covered of Cooper test in security personnel. 


\section{Subjects and Methods}

This cross sectional study research 43 security personnel who passed the inclusion and exclusion criteria in Universitas Indonesia, Jakara. This research was conducted for 3 months, starting from June 2018 to August 2018 . The purpose of this study is to give information about obesity effect to health and find correlation between waist circumference as central obesity marker and 12-minutes run test distance. We used consecutive sampling method and the data were analyzed with Spearman test for correlation test and Saphiro-wilk for normality test using SPSS 20 for Windows.

The rate of central obesity were measured by waist circumference in centimetres and the 12-minutes run test distance covered were measured in metres. Before doing the test procedure, subjects have to pass the physical examination and do warming up. Subjects also need to use sports equipments which are comfortable clothes, pants and shoes for sports.

This study had received ethical approval from the Research Module of Faculty of Medicine Universitas Indonesia with the number $747 / \mathrm{UN} 2 . F 1 . D 1 / K B K /$ PDP.01/2018. Subjects have agreed to take part of this study with informed consent.

\section{Result}

43 security personnel were assesed and shows significant negative correlation between central obesity which measured by waist circumference and Cooper test result. $(\mathrm{r}=-0.430 ; p$-value $=0.002 ; 95 \% \mathrm{CI}=-0.672-$ -0.150 ). However, Saphiro-Wilk normality test shows normal distribution for waist circumference $(p=0.237)$ when Cooper test distance has unnormal distribution $(p=0.049)$.

The mean of waist circumference which $82.69 \pm$ $9.04 \mathrm{~cm}(95 \% \mathrm{CI}=79.92-85.48)$ is still lower than Asian men cutoff for central obesity which is $90 \mathrm{~cm}$. Cooper test distance covered median was $1832.6 \mathrm{~m}$ with minimum distance $1260.40 \mathrm{~m}$ and maximum distance is $2244.30 \mathrm{~m}$ (95\% CI-1704.79 - 1871.03). However, 27.9\% subjects are classified in the central obesity level. From Cooper K classification, there are only $20.9 \%$ subjects that classified in intermediate physical fitness level and the rest are on the lower class ${ }^{8}$ (Table 1-3).
Table 1. Description of variable scores $(n=43$ subjects)

\begin{tabular}{|l|l|l|}
\hline $\begin{array}{l}\text { Waist Circumference } \\
(\mathbf{C m})\end{array}$ & $\mathbf{8 2 . 6 9 \pm 9 . 0 4}$ & $\mathbf{7 9 . 9 2 - \mathbf { 8 5 . 4 8 }}$ \\
\hline $\begin{array}{l}\text { Cooper Test Distance } \\
(\mathrm{M})\end{array}$ & $\begin{array}{l}1832.60[1260.40 \\
-2244.30]\end{array}$ & $\begin{array}{l}1704.79- \\
1871.03\end{array}$ \\
\hline
\end{tabular}

*SD $=$ Standart Deviation $\quad \mathrm{CI}=$ Confidence Interval

Table 2. Distribution of waist circumference in research subject ( $\mathrm{n}=43$ subjects)

\begin{tabular}{|c|c|}
\hline $\begin{array}{c}\text { Waist Circumference } \\
\text { Interval }\end{array}$ & $\mathbf{n}(\%)$ \\
\hline $60-69 \mathrm{~cm}$ & $5(11,6 \%)$ \\
\hline $70-79 \mathrm{~cm}$ & $9(20,9 \%)$ \\
\hline $80-89 \mathrm{~cm}$ & $17(39,5 \%)$ \\
\hline $90-99 \mathrm{~cm}$ & $12(27,9 \%)$ \\
\hline
\end{tabular}

${ }^{*}$ Maximum $=99 \mathrm{~cm}$ Minimum $=66 \mathrm{~cm}$

Table 3. Distribution of cooper test distance in research subject ( $\mathrm{n}=43$ subjects)

\begin{tabular}{|l|l|c|}
\hline \multicolumn{1}{|c|}{$\begin{array}{c}\text { Physical } \\
\text { Fitness Level }\end{array}$} & Cooper Test Distance & n (\%) \\
\hline Very Bad & $<1 \mathrm{Mil} \approx 1609,34 \mathrm{M}$ & $13(30,2 \%)$ \\
\hline Bad & $\begin{array}{l}1,0-1,24 \mathrm{Mil} \approx \\
1609,34-1995,58 \mathrm{M}\end{array}$ & $21(48,8 \%)$ \\
\hline Intermediate & $\begin{array}{l}1,25-1,49 \mathrm{Mil} \approx \\
2011,68-2397,92 \mathrm{M}\end{array}$ & $9(20,9 \%)$ \\
\hline Good & $\begin{array}{l}1,5-1,74 \mathrm{Mil} \approx \\
2414,02-2800,26 \mathrm{M}\end{array}$ & $0(0 \%)$ \\
\hline Very Good & $>1,75 \mathrm{Mil} \approx 2816,35 \mathrm{M}$ & $0(0 \%)$ \\
\hline
\end{tabular}

*Classification based on Cooper K (1968) ${ }^{\stackrel{8}{ }}$

\section{Discussion}

From 43 security personnel who took part in this study, there were 12 individuals (27.9\%) who have waist circumference more than $90 \mathrm{~cm}$. This condition is similar with central obesity proportion in Indonesia which is $28 \%$ and higher than the proportion of obesity itself which is $23.1 \%$. This result is different with central obesity proportion in China which is $10.2 \%$. Low rates of obesity in China caused by imbalance in globalization such as modern culinary lifestyle over the cities ${ }^{10}$. Asia Pacific Cohort Studies Collaboration also conduct a 
study about obesity in Asia and found 27\% of individuals in Asia are having central obesity ${ }^{11}$. Ironically, we can see that security personnel who should have greater physical fitness or lower central obesity rate found simillar with the rest people.

The mean of Cooper test distance in this study was $1787.41 \pm 271.71$ metres which 811 metres below Cooper test result in military personnel in Finlandia. Kyrolainen conducted a study from 5414 millitary personnel and got the mean of Cooper test distance was $2598 \pm 369$ metres ${ }^{12}$. The result of this study is also below the passing grade of Tes Kesamaptaan Jasmani which is $2400 \mathrm{~m}$. Therefore, security personnel of Faculty of Medicine Universitas Indonesia are not having ideal physical fitness. Unfortunatelly, studies either on security personnel or Cooper test still hardly found. Therefore, writer cannot compare the result to other study result.

Poor result of Cooper test distance on subjects from writters observation may be caused of sedentary lifestyle, there is not any routine physical exercise nor sports, unbalanced and unhealty diet and also the effect of obesity itself which increases energy expenditure for doing activities. These conditions will affect physical fitness and resulted in poor Cooper test distance.

Analysis result from both study variable shows negative significant correlation ( $p$-value $=0.002 ; \mathrm{r}=-0.430 ; 95 \%$ $\mathrm{CI}=-0.672--0.150)$. This condition is caused by negative asociation between waist circumference with cardiorespiratory fitness and muscle strength $\frac{13}{}$. This result is also supported with a study by Folgelholm, et al. who analize 951 men to find correlation between body mass index, waist circumference, cardiorespiratory fitness and muscle strength. This study shows significant negative asociation in $\mathrm{VO}_{2}$ max test $(p<0.001 ; \mathrm{r}=-0.48)$. Obesity will give bad effect for body movement because of increasing mass of the body results in reducing lower extremity strength. Beside that, increasing inertia as result of increasing mass will reduceperformance on other physical activity ${ }^{14}$ (Table 4$)$.

Table 4. Spearman correlation test result in research subject ( $\mathrm{n}=43$ subjects)

\begin{tabular}{|l|l|}
\hline & \multicolumn{1}{|c|}{ Cooper Test Distance } \\
\hline Waist Circumference & $P$-Value $=0.002$ \\
& $95 \% \mathrm{CI}=-0.672--0.150$ \\
& $\mathrm{R}=-0.430$ \\
\hline
\end{tabular}

*Spearman correlation test shows significant correlation ( $p$-value $<0.005)$;

*There is a negative correlation between variables in the study
Obesity measured with waist circumference and body mass index have been proved to influence various physical fitness test such as sit-up, long jump, shuttle run and sprint. Individuals with obesity will have worse test result than normal individuals, except in sit-up test. Excess body fat cause more effort needed when individuals do weight bearing activities. Consequently, individuals with obesity will avoid weight bearing activity because they need to spend more energy and slowly worsening their physical fitness as consequence for lack of exercise. Therefore, individuals with obesity who avoid with reducing physical exercise will have reduced result in cardiorespiratory fitness test especially at running test $\frac{15}{}$.

Decreased cardiorespiratory fitness and muscle strength concominant with increased age found in majority of security personnel. A study which do follow-up for 15 years in Finlandia police shows decline physical fitness because of increasing sedentary time. At the beginning of their career, their physical fitness were great as result of training given in the police academy. However, their fitness are worsening together with increasing sedentary time and resulting in worsening work index ${ }^{\frac{16}{6}}$. Increasing sedentary lifestyle which studied in the study was also found in the subjects. Therefore, there is a possibility for increasing sedentary lifestyle to affect this study result.

With this research, hopefully it can motivate other researchers to pay attention security personnels. Companies will also pay more attention to the physical fitness of their security officers and provide training for their employees. In the end, maintained physical fitness will prevent diseases in security personnel and improve work performance. However, this study still has disadvantages. There were still factors that cannot be controlled and affected the results of research due to the study design used. The number of subjects used is also small so that a larger number of subjects is needed to provide more precise results.

\section{Conclusion}

From this study, we can conclude that a quarter of subject have central obesity which similar with central obesity rate in Indonesia. The mean of Cooper test distance covered is below the passing grade of Tes Kesamaptaan Jasmani which is $2400 \mathrm{~m}$. And finally, this study found that there is a negative correlation between central obesity with cardiorespiratory fitness which measured by Cooper test distance. This condition may be caused by 
another affecting factors such as diet, physical exercise, physiological different between races and habits which have not been studied in this study.

For future studies, it is hoped to pay attention among variables such as the amount of exercise, age and gender due to affecting physical fitness. The suggested study design was case control or cohort so that the results obtained gave a higher level of trust. Then, the number of subjects is also enlarged to get more significant results.

\section{Acknowledgment}

I would like to thank dr. Listya Tresnanti Mirtha, MD. SportsMed. form Sports Medicine Division, Department of Community Medicine, Faculty of Medicine Universitas Indonesia for allowing and encouraging me to run this study. In addition, we thank all doctors, staffs and security personnels of Faculty of Medicine Universitas Indonesia for their sincere help and encouragement.

\section{Conflict of Interest}

The authors affirm no conflict of interest in this study.

\section{References}

1. Physical activity [Internet]. World Health Organization. 2017 [cited 14 August 2017]. Available from: http://www. who.int/mediacentre/factsheets/fs385/en/.

2. Buku Penyajian Data dan Informasi Kepemudaan dan Olahraga [Internet]. Kemenpora. 2017 [cited 14 August 2017]. Available from: http://www.kemenpora.go.id/index/ preview/statistik/10417.

3. Non communicable diseases [Internet]. World Health Organization. 2017 [cited 14 August 2017]. Available from: http://www.who.int/mediacentre/factsheets/fs355/en/.

4. Hassel G, Milroy J, Orsini M. Investigating motivation for physical activity among minority college females using the BREQ-2. Journal of Student Research. 2015; 094(1): 40-44.

5. Penerimaan Tamtama TNI AD2018 [Internet]. TNI Angkatan Darat. 2018 [cited 2018 May 20]. Available from: http://ad.rekrutmen-tni.mil.id/berita/materi-seleksi/ tamtama-ad.

6. Indonesia Diabetes Country Profile [Internet]. WHO. 2017 [cited 31 August 2017]. Available from: http://www.who. int/entity/diabetes/country-profiles/idn_en.pdf?ua=1.

7. Hassan M, Ahmad N, Adam S, Nawi A, Ghazi H. Abdominal obesity indicators: Waist circumference or waist-to- hip ratio in Malaysian adults population. International Journal of Preventive Medicine. 2016; 7(1): 82. https://doi. org/10.4103/2008-7802.183654. PMid: 27330688, PMCid: PMC4910307.

8. Cooper K. A Means of Assessing Maksimal Oxygen Intake. JAMA. 1968; 203(3): 201. https://doi.org/10.1001/ jama.1968.03140030033008, https://doi.org/10.1001/jama. 203.3.201. PMid: 5694044.

9. Harbuwono D, Pramono L, Yunir E, Subekti I. Obesity and central obesity in Indonesia: Evidence from a national health survey. Medical Journal of Indonesia. 2018; 27(2): 114. https://doi.org/10.13181/mji.v27i2.1512.

10. Hu L, Huang X, You C, Li J, Hong K, Li P et al. Prevalence of overweight, obesity, abdominal obesity and obesity-related risk factors in southern China. PLOS ONE. 2017; 12(9): e0183934. https://doi.org/10.1371/journal.pone.0183934. PMid: 28910301, PMCid: PMC5598943.

11. Mhurchu C, Parag V, Woo J, Lam T, Woodward M, et al. Central obesity and risk of cardiovascular disease in the Asia Pacific Region. Acia Pac J Clin Nutr. 2006; 15(3): 287-292.

12. Kyrolainen H, Hakkinen $\mathrm{K}$, Kautiainen $\mathrm{H}$, et al. Physical fitness, BMI and sickness absence in male military personnel. Occupational Medicine. 2008; 58(4): 251-256. https://doi.org/10.1093/occmed/kqn010. PMid: 18296685.

13. Díez-Fernández A, Martínez-Vizcaíno V, Torres-Costoso A, Cañete García-Prieto J, Franquelo-Morales P, SánchezLópez M. Strength and cardiometabolic risk in young adults: The mediator role of aerobic fitness and waist circumference. Scandinavian Journal of Medicine and Science in Sports. 2018; 28(7): 1801-1807. https://doi. org/10.1111/sms.13077. PMid: 29469938.

14. Fogelholm M, Malmberg J, Suni J, et al. Waist circumference and BMI are independently associated with the variation of cardio-respiratory and neuromuscular fitness in young adult men. International Journal of Obesity. 2006; 30(6): 962-69. https://doi.org/10.1038/sj.ijo.0803243. PMid: 16432537.

15. Gonzalez-Suarez C, Caralipio N, Gambito E, Reyes J, Espino R, Macatangay R. The association of physical fitness with body mass index and waist circumference in Filipino Preadolescents. Asia Pacific Journal of Public Health. 2012; 25(1): 74-83. https://doi.org/10.1177/1010539511412764. PMid: 22865721.

16. Sorensen L, Smolander J, Louhevaara V, Korhonen O, Oja P. Physical activity, fitness and body composition of finish police officers: A 15-year follow-up study. Occupational Medicine. 2000; 50(1): 3-10. https://doi.org/10.1093/ occmed/50.1.3. PMid: 10795384. 